\title{
The Significance Difference on Entrepreneurial Profile toward Entrepreneurial Personality in Micro and Small Business: Malaysia Creative Industry
}

\author{
Muhammad Abi Sofian Abdul Halim \\ Faculty of Business Management, Universiti Teknologi MARA \\ 21080 Kuala Terengganu, Terengganu, Malaysia \\ Tel: 60-13-920-4322Ｅ-mail: abisofian@tganu.uitm.edu.my
}

Associate Professor Dr Shaladin Muda

Faculty of Business and Economics, Universiti Malaysia Terengganu

21300 Kuala Terengganu, Terengganu, Malaysia

Tel: 60-19-934-6600 E-mail: shaladdin@umt.edu.my

Associate Professor Dr Wan Abd Aziz Wan Mohd Amin

Faculty of Business and Economics, Universiti Malaysia Terengganu

21300 Kuala Terengganu, Terengganu, Malaysia

Tel: 60-19-988-5293 E-mail: ziza@umt.edu.my

Dr Ahmad Munir Mohd Salleh

Universiti Malaysia Terengganu, 20300 Kuala Terengganu, Terengganu, Malaysia

Tel: 60-13-983-0420

Received: August 15, 2011

doi:10.5539/ass.v8n3p236
Accepted: December 2, $2011 \quad$ Published: March 1, 2012

URL: http://dx.doi.org/10.5539/ass.v8n3p236

\begin{abstract}
In literature, an essential of entrepreneurial profile toward entrepreneurial personality become significant, particularly in developing the factor of need for achievement, locus of control, creativity, innovative and grab market opportunities. Therefore, this paper postulated that inculcation of entrepreneurial profile among creative entrepreneurs toward entrepreneurial personality. This survey study further identified eight items in entrepreneurial profile that relate to the identification of entrepreneurial personality, there are; gender, age, education, and field of study which are grouping under demographic profile; and, zones of operation, paid-capital, sales turnover, and paid-up capital are under business profile. This study was conducted by distributing questionnaires to 309 creative entrepreneurs in five zones in Malaysia, there are; East-Coast Malaysia, West-Coast Malaysia, North Peninsular Malaysia, South Peninsular Malaysia, and East Malaysia. However, the data revealed that six out of eight items of entrepreneurial profile are not significant differences toward the entrepreneurial personality. There are only the items of zones of operations and numbers of employees are significantly differences toward the entrepreneurial personality. In general, the results indicated that most of items in entrepreneurial profile are not really important to consider as a factor in implementing the program that related to the development of entrepreneurial personality, especially in Malaysia creative industry.
\end{abstract}

Keywords: Entrepreneurial personality, Creative industry, Micro and small business

\section{Introduction}

The successful entry of micro and small creative business into the global market of consumer goods such as; batik, ceramics, wood-carving, bamboo-craft, rattan craft, silk, pewter, and pewter in early 2000s clearly proved 
that Malaysian creative entrepreneurs could no longer depend on local market as the primary source of economic growth. The creative industry has also been identified as one of the keys to transform the Malaysian economy. This is due to the reason that several sectors in creative industry could be potentially grown and developed as they could enhance innovation and could result in improved productivity and the economy. In fact, the creative industry in Malaysia has contributed to the gross domestic products, and it is also currently growing at a faster rate in economy (Rais Yatim, 2006).

Creative industry has been considered as a new practice in Malaysia and it has also been established in several sectors related to the needs of idea development in art composition through creativity. In the United Kingdom, the creative industry has become one of the main economic sectors which contributed to the gross domestic product, with the growing rate faster than any other economic sectors in the years of 1997 to 2003 (Einarsson, 2002). In addition, it had also expanded by an average of 6 percent per annum as compared to previous years which was only 2 percent per annum (Carey, Naudin, 2006). Similarly to the United Kingdom, Malaysia has nowadays given a positive feedback towards the development of creative industry in the country (Hatta Azad Khan, 2006).

Entrepreneurship and micro and small business are closely linked to the establishment of entrepreneurial personality, especially in creative industry. Furthermore, the identity and business background also considered as a profile of entrepreneurs that should be emphasis to develop the entrepreneurial personality. Consequently, some academicians and scholars such Wan Hashim Wan Teh (1996), Hatta Azad Khan (2006), and Ghulam Sarwar (1989) were stated that most of creative entrepreneurs in micro and small business are not similarly assumed that the important of demographic and business profile toward the developing of entrepreneurial personality. Thus, is there a significant difference in entrepreneurial personality among the creative entrepreneurs with different identity in entrepreneurial profiles? Therefore, the purpose of this study is to determine whether there is a significant difference of entrepreneurial personality among creative entrepreneurs in Malaysia creative industry.

\section{Background of Malaysia Creative Industry}

According to Rais Yatim (2006), the Ministry of Information, Communication and Culture has taken the responsibility to ensure the rapid development of creative industry in Malaysia. Malaysia has vast cultural and creative resources in the fields of performing arts, visual and fine arts, Islamic calligraphy and Jawi writing, films, arts education, literary works and crafts which can be further developed and exploited. During the Ninth Malaysian Plan, the economic potential of the creative cultural industry would be further developed through close collaboration between the public and private sectors (Kraftangan Malaysia, 2008). In order to facilitate the development of the creative industry and to ensure its contribution to the economy, the Government will continue to provide encouraging environment as well as supportive infrastructure. The development of creative industry will also be highly encouraged by the government. The government will provide various facilities at the state level, in which the state cultural centers and galleries could be utilized to promote the activities. In addition, the government will also provide business premises to entrepreneurs to promote their crafts and products.

Malaysia Handicraft Development Corporation or known as Kraftangan Malaysia is a government agency which is responsible for the implementation of the government policy in developing entrepreneurial personality among creative entrepreneurs in the Malaysian creative industry. Since the emergence of a new concept of entrepreneurial personality, commitment and business performance have become two important aspects in producing new creative entrepreneurs in Kraftangan Malaysia. Creative entrepreneurs have to work within artistic values and commercial realities to ensure successful implementation of the government policies in the creative industry. Even though the development of entrepreneurial personality has also become an important field of enquiry in relation to the academic study of entrepreneurship and the development of new entrepreneurs, it remains an area which is not well understood among creative industry practitioners in Malaysia.

\section{Literature Review}

The term entrepreneurial personality refers to individuals who possess the ability to take risk, innovativeness, knowledge of the market functions, marketing skills and business management skills; in which these personality traits influence cooperation, networking and enable them to be independent when running a business (Littunen, 2000). With regards to this current study, the term entrepreneurial personality relates to people who have a sense of need for achievement, locus of control, are creative, innovative and able to grab market opportunities (Stevenson, 1983; McClleland, 1961; Shane et al, 2003; Rotter, 1966). As a matter of fact, the term entrepreneurial personality is a combination of two different words, they are; entrepreneurship and personality. According to Gartner (1990), the term entrepreneurship describes unique personality characteristics and abilities 
which one possesses such as creativity, vision, commitment, perseverance, autonomy, locus of control, and ability to take risk when running a business. An individual's experience, behavior and education background significantly contribute to entrepreneurial personality. Meanwhile, the term personality refers to a person's typical patterns of attitudes, needs, characteristics, and behaviors (Lefton, 1994). According to McClelland (1961), entrepreneurial personality is an individual who is highly motivated in a business, innovative in a product development; able to strategize in a competitive market and capable to manage a business independently. The terminology of personality traits describes the social or human study which analyzes the attitude, perception, learning, thinking, character and traits of people towards an issue or situation. Shane et al (2003) have revealed that entrepreneurial personality is highly significant to the business performance. The entrepreneurs with entrepreneurial personality are people who already have several personality traits, such as; need for achievement (McClelland, 1961), locus of control (Rotter, 1966), self-efficacy (Bandura, 1997), goal setting (Priem, 2001), and risk taking (McClelland, 1961). Similarly, the theory of personality in psychology also agrees that people will not always act in the same way, even when faced with the same situation. Normally, different people will react in different ways towards a similar situation (Larsen et al, 2008). This is due to the reason that each individual has different attitudes, needs, characteristics, and behaviors which influence and shape his or her personality. Therefore, the concept of personality is significantly related to the entrepreneurial characteristics and traits.

In spite of the impact of entrepreneurial factors on the business performance, studies on the role of entrepreneurial profile have been excluded with the studies of several factors in a demographic and business profile. This variable investigates whether the factors of entrepreneurial profile moderate the relationship of entrepreneurial personality. McKenna (2005) has founded in his research that there is no relationship that appears between demographic variables (such as age and gender) on the business management practice. However, Danes et al (2007) have argued in their studies that gender in a demographic profile has a significant moderating effect on business management practices, especially on a family business performance. According to the findings, evidence for a gender difference in gross revenue of female and male owned family firms when controlled by family business management and innovation practices. Therefore, gender's factor in a demographic profile highly contributes to the significance difference between male and female towards the performance of business. Meanwhile, Elizur et al (2001) have looked into the relationship between work values, gender and organizational commitment. A moderated regression analysis was done using commitment as the dependent variables, work values as the independent variable, and gender was the moderating variable. They found that work values, gender and commitment are related to each other and the interaction terms were highly significant. As a result, gender as part of demographic profiles was significant in a study of relationship between entrepreneurial personality and business performance.

In addition, Loscoco et al (1991) have added that it is not only gender that has a significant relationship with the entrepreneurial personality and business performance, but other demographic and business profiles have to be taken into consideration, such as; education, managerial skills, and experience. Cherrington et al (1979), have also argued that demographic indicators (age, education and seniority) were correlated with several work values among entrepreneurs, such as; the importance of work, pride in one's craftsmanship and importance of money. As well as mentioned by Danes et al (2007), Loscoco et al (1991), and Cherrington et al (1979), we can conclude that demographic and business profiles seem to play a role in explaining the relationship of entrepreneurial profile towards entrepreneurial personality.

\section{Hypothesis}

As well as to answer the research questions and objective, several hypothesis or testable statements has been drawn to test the relationship between variables. Generally, this hypotheses are divided into two parts of entrepreneurial profiles. The first part of entrepreneurial profile is demographic profile which comprises four hypotheses, they are;

H1: There would be a significance difference in entrepreneurial personality among the male and female creative entrepreneurs

$\mathrm{H} 2$ : There would be a significance difference in entrepreneurial personality among creative entrepreneurs with different age groups

H3: There would be a significance difference in entrepreneurial personality among creative entrepreneurs with different education level

H4: There would be a significance difference in entrepreneurial personality among creative entrepreneurs 
with different fields of study

Meanwhile, the second part of entrepreneurial profile is business profile which comprises of four hypotheses, they are;

H5: There would be a significance difference in entrepreneurial personality among creative entrepreneurs with different business zones of operation

H6: $\quad$ There would be a significance difference in entrepreneurial personality among creative entrepreneurs with different amount paid-up capital

H7: There would be a significance difference in entrepreneurial personality among creative entrepreneurs with different amount of sales turnover

H8: There would be a significance difference in entrepreneurial personality among creative entrepreneurs with different number of employees

\section{Research Methodology}

This study is a quantitative in nature where the purpose is to measure the differences of entrepreneurial profile among micro and small business in creative industry toward the perception of entrepreneurial personality. In a study of entrepreneurial personality it is possible to discriminate factors that influence the entrepreneurial profile which has two separate dimensions, such as; demographic profile and business profile. The demographic profile examines the personal background, such as; gender, age, level of education, and field of study. Meanwhile, the business profile looks at the business background that includes; zones of operations, paid-up capital, sales turnover, and number of employees.

\subsection{Variables and Indicators in Questionnaire}

On the other hand, the perception of entrepreneurial personality was divided into five variables there are; need for achievement, locus of control, creativity, innovative, and grab market opportunities. The questionnaire was properly designed to ensure that the items would properly structure, focused, and phrased that the data can be statistically analyzed. Closed-ended questionnaires most of which were likert-type scale. The likert scale questions are ranging from five scales, one to five (1-5), which is; 1- strongly dissatisfied, 2 - dissatisfied, 3neutral, 4- satisfied and 5- strongly satisfied. Table 1 show the list of variables and indicators which uses likert scale as measurement in questionnaire.

$<$ Insert Table 1 here $>$

\subsection{Population and Sample}

As this study focus on investigation of entrepreneurial personality among creative entrepreneurs in Malaysia creative industry, a survey investigation was attempted to describe the entrepreneurial profiles of respondents which are associated with the entrepreneurial personality. This study concentrated on creative entrepreneurs in Malaysian Handicraft development Agency. According to the statistic produced by Kraftangan Malaysia (2008), there are 1,347 creative entrepreneurs from the whole of Malaysia are registered under this agency. Most of them are operating as a producer, distributor, agent, and retailer.

$<$ Insert Table 2 here $>$

In order to provide an equal chance to all populations in Kraftangan Malaysia, researcher has made a decision to use random sampling in this study which comprises 309 respondents. Researcher has divided sub-sample into five zones of operations which have been developed by Kraftangan Malaysia, they are; North-Peninsular Malaysia, East-Coast Malaysia, West-Cost Malaysia, South-Peninsular Malaysia, and East Malaysia. In using of random sampling in zones of operations, researcher has used percentage to give an equal chance to all the creative entrepreneurs in five zones in Malaysia. However, there are only 295 of creative entrepreneurs who have returned the questionnaire to the researcher. Table 2 shows the percentage of sub-population and sub-sample based on zones of operations.

\section{Analysis and Finding}

According to Fah \& Hoon (1999); Piaw, (2009); and Cooper \& Emory (1995), the study of significant difference in a statistical analysis firmly is to test the differences in mean scores between groups or in comparing how two or more groups scores are distributed across certain response categories. It is common for researchers to investigate whether two or more groups are significantly different with respect to a certain attitude, characteristic or behavior (Sekaran, 2005). Therefore, this research had done a statistical analysis to find out the result of significant difference of means between groups of creative entrepreneurs in Kraftangan Malaysia. This analysis 
also had investigated the $\mathrm{H} 1, \mathrm{H} 2, \mathrm{H} 3$ and $\mathrm{H} 4$ in the part of demographic profile, and hypotheses $\mathrm{H} 5, \mathrm{H} 6, \mathrm{H} 7$, and H8 in the part of business profile.

As all five independent variables (e.g. need for achievement, locus of control, creativity, innovative, grab market opportunities) in this research were not normal distributions, therefore, this data had violating the stringent assumptions of an independent t-test and one-way analysis of variance (ANOVA). Furthermore, the non-parametric test was used to test the differences between groups in Kraftangan Malaysia towards entrepreneurial personality. There were two types of non-parametric analysis done in this research. They were Mann-Whitney U Test and Kruskall-Wallis H Test. Basically, the concept of Mann-Whitney U Tests was used to compare the mean of two sets of data obtained from the same group of samples (similarly with the independent t-test). It meant that each sample would have two scores to be compared with each other (Piaw, 2009). Meanwhile, Kruskall-Wallis Test was a statistical test used to compare the mean of three or more independent sample groups (similarly with the ANOVA). This test would determine whether there was a significant difference in the population mean (Zukarnain Zakaria et al, 2001).

\subsection{Demographic Profile}

Demographic profile had become the first part of entrepreneurial profile to study the background of respondents. However, there were only four items that were used to measure the significant difference of means between groups in this study. These included gender (hypothesis 1), age (hypothesis 2), level of education (hypothesis 3), and field of study (hypothesis 4).

In hypothesis 1 , there were $47.5 \%$ (140 respondents) of the total respondents were males and $52.5 \%$ (155 respondents) were females. Since this study was aimed at addressing the phenomenon of gender affected the entrepreneurial personality, Mann-Whitney Test was used to investigate the significant difference between male and female among respondents in this study. Furtehrmore, it indicated that means for both males (153.3) and females (143.2) were nearly similar towards the personality of entrepreneurship. In a table 3, the results also indicated there was no significant difference $(u=10108.0, p=0.310)$ in relationship with the entrepreneurial personality. Therefore, we concluded that hypothesis 1 was unaccepted.

In terms of age, the number of respondents according to the sub-item that had been classified in this research were $1.4 \%$ ( 4 frequency) in the age of below 19 years old, 17.3\% (51 frequency) in the age between $20-29$ years old, $23.1 \%$ ( 68 frequency) in the age between $30-39$ years old, $31.2 \%$ ( 92 frequency) in the age between $40-49$ years old, and $27.1 \%$ ( 80 frequency) are above 50 years old. In comparing the group means in the age factor, there were five groups that had been classified accordingly. The Kruskall-Wallis test was carried out to determine the difference in means between groups in the age factor. Basically, the means score for all for sub-items in this item were closely similar. As indicated in Table 3, the significant results showed was 0.616 which meant no significant difference between age groups in a relationship with the entrepreneurial personality. Therefore, we concluded that hypothesis 2 was unacceptable.

The level of education for the respondents in this research had been divided into five levels. They were $66.4 \%$ (196 respondents) who had school level education, 20.7\% (61 respondents) who had certificates, 9.8\% (29 respondents) who were in the diploma level, and only $3.1 \%$ ( 9 respondents) who have degrees. Meanwhile, there were no respondents for master and $\mathrm{PhD}$ levels. This analysis was aimed to investigate whether there were differences in the levels of education with the entrepreneurial personality. Through Kruskall-Wallis Test, indicated that mean rank in all sub-items were closely similar which the range of 140.70 to 180.57 . As shown in Table 3, the significant value of 0.098 had respectively been demonstrated that there was no significant difference between groups for the levels of education towards entrepreneurial personality. Therefore, hypothesis 3 was rejected.

As part of this analysis was to study the differences of groups in the field of studies, four groups had been classified accordingly to the field background of respondents. There were 159 of respondents $(53.9 \%)$ who were in the field of Business, 21 respondents (7.1\%) in the field of Science and Technology, 38 respondents (12.9\%) are in Social Sciences, and 77 respondents $(26.1 \%)$ were in the field of Arts. Throughout the analysis of Kruskall-Wallis test, it indicated that there was no significant difference when referring to the entrepreneurial personality attributes regardless of the groups' fields of study. The significant value of 0.772 respectively demonstrated the existing of none significant difference. As a solution, hypothesis 4 was rejected.

$<$ Insert Table 3 here $>$

\subsection{Business Profile}

Meanwhile, the second part of entrepreneurial profile was to study the business background of respondents. However, there were only four items that were used to measure the significant difference of means between 
groups in this study. They were zones of operations (hypothesis 5), paid-up capital (hypothesis 6), sales-turnover (hypothesis 7), and number of employees (hypothesis 8 ).

There were five zones that had been classified based on the positions of states in Malaysia. There were the East-coast of Malaysia, West-coast of Malaysia, South-peninsular Malaysia, North-peninsular Malaysia, and East Malaysia. In terms of numbers of respondents, there were; $21 \%$ respondents (62 frequencies) from East-coast Malaysia, 31.9\% respondents (94 frequencies) from North-peninsular Malaysia, $7.4 \%$ (22 frequencies) from West-coast Malaysia, 8.1\% (24 frequencies) from South-peninsular Malaysia, and 31.5\% (93 frequencies) from East Malaysia. The Krukall-Wallis test result indicated a significant difference in the means of five zones implying of not similar to the sample means between groups. In other words, the result showed evidence that creative entrepreneurs from different zones in Malaysia had significant differences $(p=0.000)$ towards the personality of entrepreneurship which were highly influence to the business performance. As a solution, hypothesis 5 was accepted.

Paid-up capital is an item to measure the level of business size; micro, small, or medium scale. In fact, Small Medium Industry Development Corporation is a government agency has determined the size of business in Malaysia, where micro size business is a paid-up capital of less than RM50,000; small business is paid-up capital in between RM50,001 - RM500,000; and the amount of paid-up capital of medium business size is between RM500,001 -RM2,500,000 (Chamhuri Siwar et al, 1995). However, there were 83\% (245 frequencies) respondents whom were from micro business size, followed by $14.6 \%$ (43 frequencies) of respondents from small business size; and only $0.7 \%$ ( 2 frequencies) respondents from medium business size. Kruskall-Wallis test was used to compare the means of group of difference paid-up capital towards entrepreneurial personality and it indicated that different groups in a paid-up capital had no significant difference in the means towards the entrepreneurial personality. Tables 4 also showed that the significant value was 0.710 and above 0.05 , which meant that groups under paid-up capital had not significant difference towards entrepreneurial personality. Therefore, hypothesis 6 was unacceptable.

There were; $87.5 \%$ respondents (258 frequency) involved in sales turnover of less than RM250,000 which was considered as micro business scale; $4.7 \%$ respondents (14 frequencies) were in sales turnover of between RM250,001 - RM10,000,000 (small business scale); and no respondent was involved in a sale turnover of between RM10,000,001 - RM25,000,000 which was considered as a medium business scale. In terms of comparing the group means in the factor of sale turnovers, there were three groups that had been classified accordingly, however, only two groups which were involved. Therefore, Mann-Whitney U Test was carried out to determine the difference in means between two groups in the factor of sale turnovers. The Mann-Whitney U results showed that mean rank between micro and small business were closely similar. Therefore, Table 4 had concluded that the significant value of 0.255 had no significant difference between micro and small business towards the relationship with the entrepreneurial personality. Therefore, it was concluded that hypothesis 7 was rejected.

There were three categories identified accordingly such as micro business scale which have employee who were less than five; small business scale with the number of employees around 6 to 24 employees, and medium business which had above 25 employees. Therefore, the number of employees in a micro business scale is 268 respondents $(90.8 \%)$, small business scale, 27 respondents $(9.2 \%)$ and no respondent in a medium business scale. This analysis aimed to investigate whether there were differences in the number of employees with entrepreneurial personality. Through Mann-Whitney $U$ test, the analysis indicated that there was significant difference of groups in the numbers of employees towards entrepreneurial personality. The Mann-Whitney $U$ test result indicated a significant difference in the means of two groups implying as not similar to the sample means between groups. In other words, the result showed evidence that creative entrepreneurs from different business scale in the context of numbers of employees had significant differences $(p=0.004)$ towards the personality of entrepreneurship. Therefore, the hypothesis 8 is acceptable.

$<$ Insert Table 4 here $>$

\section{Discussion and Recommendations}

These analysis and findings are disclosed from the survey research on creative entrepreneurs that have been conducted in the five zones of Kraftangan Malaysia. In addition, it reviews the findings which have provided answers to the research questions and hypotheses towards the achievement of the research objectives. As in the data of variables in entrepreneurial personality are not in normal distribution, the non-parametric is adopted to measure the association of nominal and ordinal data in entrepreneurial profile with independent variables (Likert scale). Hence, two of non-parametric tests have been used in this study to measure the association of 
entrepreneurial profile and entrepreneurial personality. They are Mann-Whitney $U$ test which compares the mean of two sets of data obtained from the same group of samples and Kruskal-Wallis H test which compares the mean of three or more independent sample groups.

As mentioned before, these analyses provide answers for four hypotheses in the demographic profile part ( $\mathrm{H} 1$, $\mathrm{H} 2, \mathrm{H} 3, \mathrm{H} 4)$ and four hypotheses in the business profile part $(\mathrm{H} 5, \mathrm{H} 6, \mathrm{H} 7, \mathrm{H} 8)$. The results have revealed that all items in the demographic profile have no significant difference with regards to entrepreneurial personality. However, only two items in the business profile have significance toward the entrepreneurial personality. They are zones of operations ( $\mathrm{p}=0.000)$, and number of employees $(\mathrm{p}=0.004)$, as in hypotheses 5 and 8 . Generally, it gives evidence that all the creative entrepreneurs in five zones of operations are mostly similar in application of locus of control, creativity, innovative, and grab market opportunities in their business. However, some of them do not have similar personalities in entrepreneurship in terms of the number of employees and zones of operations in their business.

Besides that, the government also should take initiative to specify and structure their policies in the development of entrepreneurial personality, as well as what they have implemented in developing entrepreneurial skill and knowledge in entrepreneurial development programmes before. Instead of the government's initiatives, academicians also play very prominent role to develop entrepreneurial personality. These include academicians' collaboration with industrial practitioners, curriculum development, and entrepreneurship publishing. In addition, it highlights that implementation of closed collaboration between academicians and entrepreneurial practitioners will give an ideal condition to develop entrepreneurship activities through consultations, research in entrepreneurship, publications in entrepreneurship, and entrepreneurship training.

It has been recommended that the types and levels of entrepreneurial profile (both demographic profile and business profile) are effective with the performance of entrepreneurial personality. According to Danes et al (2007), Loscoco et al (1991) and Cherrington et al (1979), it is not only gender that has significant relationship with the entrepreneurial personality, but other demographic and business profiles have to be taken into consideration. They are factors such as gender, age, level of education, field of study, zones operation, paid-up capital, sales turnover and number of employees. Consequently, the results of this study indicate that all demographic factors are not significantly difference. However, this study has demonstrated the findings that only two variables of business profiles have significant differences towards the concept of entrepreneurial personality. They are the relationship of zones of operations and entrepreneurial personality (H5), and the relationship of number of employees and entrepreneurial personality (H8). Therefore, these results indicate that the items of entrepreneurial profile are not vital factors to differentiate creative entrepreneurs towards the government's assistance in the entrepreneurial personality development. Furthermore, these findings not supported the literatures which are highlighted by Danes et al (2007), Loscoco et al (1991) and Cherrington et al (1979). However, there are only two factors (zones of operation and numbers of employees) that become as prominent factors for the government to consider whenever they intend to plan and implement any assistance and policies for the creative entrepreneurs in Kraftangan Malaysia.

\section{Conclusion}

As a summary, the term entrepreneurial personality in this study exposes several personality traits, such as, need for achievement, locus of control, creative, innovative, and grabs the market opportunities. In general, this quantitative analysis reveals that the differences of entrepreneurial profile toward entrepreneurial personality are not significantly associated unless for the item of zones of operation and number of employees. These findings indicated that the factors of entrepreneurial profile are generally not significant to the entrepreneurial personality for both micro and small business in Malaysia creative industry. The findings and conclusion of this research will give future direction to academicians, industrial practitioners and government agencies to plan and implement the policy of entrepreneurship in the Malaysian creative industry.

\section{References}

Bandura, A. (1986). Social Foundations of Thought and Action. New Jersey: Prentice Hall.

Carey, C. \& Naudin, A. (2006). Enterprise Curriculum for Creative Industries Students: An Exploration of Current Attitudes and Issues. Journal of Education and Training, 48(7), 222-238.

Casson, M. (1982). The Entrepreneur: An Economic Theory. Oxford: Martin Robertson.

Chamhuri Siwar., Abdul Hamid Jaafar \& Ahmad Mad Zin. (1995). Industri Desa Semenanjung Malaysia. Bangi: Universiti Kebangsaan Malaysia. 
Cherrington, D.J., Conde, S.J. \& England, J.L. (1979). Age and Work Values. Academy of Management Journal, 22(6), 103-121.

Cooper, D.R. \& Emory, C.W. (1995). Business Research Methods (5 ${ }^{\text {th }}$. Edition).USA: McGraw-Hill.

Danes, S.M., Stafford, K. \& Loy, J.T.C. (2007). Family Business Performance: The Effects of Gender and Management. Journal of Business Research, 60(5), 84-102.

Einarsson, A. (2002). Entrepreneurship as a Part of the Creative Industries within the Cultural Sector in a Small Society. Review of International Comparative Management, 1(13), 208-229.

Elizur, D. \& Koslowsky, M. (2001). Values and Organizational Commitment. International Journal of Manpower, 22(7), 119-131. http://dx.doi.org/10.1108/01437720110408967

Fah, L.Y. \& Hoon, K.C. (1999). Introduction to Statistical Analysis in Social Sciences Reserch. Selangor: Venton Publishing.

Gartner, W.B. (1990). Some Suggestions for Research on Entrepreneurial Traits and Characteristics. Entrepreneurship Theory and Practice, 5(2), 15-28.

Ghulam Sarwar. (1989). Pemupukan dan Penggalakan Kesenian Daerah: Satu Usaha Kearah Pengwujudan Kesenian Malaysia. Himpunan Kertas Kerja Bengkel Kepimpinan dan Pengajian Kebudayaan, Kementerian Kebudayaan dan Pelancongan Malaysia, Kuala Lumpur.

Hatta Azad Khan. (2006). Industri Budaya dan Kreatif dalam Konteks Globalisasi. Procedding paper for Persidangan Seni Budaya dan Warisan Pendidikan Seni Budaya dan Warisan diabad 21: Teori dan Praktis. PWTC, Kuala Lumpur.

Kraftangan Malaysia. (2008). Portal Rasmi Perbadanan Kemajuan Kraftangan Malaysia. [Online] Available: www.kraftanganmalaysia.com.my

Larsen, R.J. \& Buss, D.M. (2008). Personality Psychology: Domains of Knowledge About Human Nature. New York: MCGraw-Hill.

Lefton, L.A. (1994). Psychology (5 $5^{\text {th }}$. Edition). USA: Paramount Publishing.

Littunen, H. (2000). Entrepreneurship and the Characteristics of the Entrepreneurial Personality. International Journal of Entrepreneurial Behavior \& Research, 6(6), 103-121. http://dx.doi.org/10.1108/13552550010362741

Loscoco, K.A., Joyce, R., Richard, H. \& John, K.A. (1991). Gender and Small Business Success: An Inquiry into Women's Relative Disadvantage. Journal of Organizational Transformation \& Social Change, 5(2), 32-25.

McClelland, D.C. (1961). Characteristics of Successful Entrepreneurs. Journal of Creative Behavior, 21(3), 53-67.

McKenna, S. (2005). Organizational Commitment in the Small Entrepreneurial Business in Singapore. Journal of Cross Culture Management, 12(2), 37-52.

Piaw, C.Y. (2009). Statistik Penyelidikan Lanjutan: Ujian Regresi, Analisis Faktor dan analisis Sem. Kuala Lumpur: McGraw-Hill.

Priem, R. L. \& Shaffer, M. (2001). Resolving Moral Dilemmas in Business: A Multi-Country Study. Business \& Society, 40(5), 197-220. http://dx.doi.org/10.1177/000765030104000204

Rais Yatim. (2006). Ministry of arts, Culture and Heritage: Keynote address in Majlis Perasmian Persidangan Seni Budaya dan Warisan. Putra World Trade Center. Kuala Lumpur.

Rotter, J. B. (1966). Generalized expectancies for internal versus external control of reinforcement. Psychological Monographs: General and Applied, 80(1), 1-28. http://dx.doi.org/10.1037/h0092976

Sekaran, U. (2005). Research Methods for Business: A Skill Building Approaches. USA: John Wiley \& Sons.

Shane, S., Locke, E.A. \& Collins, C.J. (2003). Entrepreneurial Motivation. Human Resources Management Review, 13(5), 86-102.

Stevenson, H. (1983). A Perspective on Entrepreneurship. Harvard Business School Working Paper, 9(21), 384-131.

Wan Hashim Wan The. (1996). Malay Handicraft Industries: Origins and Development. Kuala Lumpur: Dewan Bahasa \& Pustaka.

Zukarnain Zakaria \& Hishamuddin Md Som. (2001). Analisis Data Menggunakan SPSS Windows. Johor Bharu: UTM Publishing. 
Table 1. An arrangement of items in a questionnaire

\begin{tabular}{|c|c|c|c|c|}
\hline Sections & Parts/ Indicators & $\begin{array}{l}\text { Number of } \\
\text { Items }\end{array}$ & Total & Scale \\
\hline \multirow{2}{*}{$\begin{array}{c}\mathrm{A} \\
\text { Entrepreneurial Profile }\end{array}$} & Demographic profile & 6 & & \multirow{2}{*}{$\begin{array}{c}\text { Rating } \\
\text { scale }\end{array}$} \\
\hline & Business profile & 13 & 19 & \\
\hline $\mathrm{B}$ & Better improvement & 3 & & \multirow[t]{4}{*}{ Likert scale } \\
\hline \multirow[t]{3}{*}{ Need for Achievement } & Challenging task & 3 & & \\
\hline & Set the target & 3 & & \\
\hline & Problem solving & 4 & 13 & \\
\hline \multirow{4}{*}{$\begin{array}{c}\text { C } \\
\text { Locus of Control }\end{array}$} & Controlling owns life & 3 & & \multirow[t]{4}{*}{ Likert scale } \\
\hline & Self confidence & 3 & & \\
\hline & Influence events & 3 & & \\
\hline & Turn thought into action & 3 & 12 & \\
\hline $\mathrm{D}$ & Key value in entrepreneurship & 4 & & \multirow[t]{4}{*}{ Likert scale } \\
\hline \multirow[t]{3}{*}{ Creativity } & Develop new product & 4 & & \\
\hline & Differentiate product & 5 & & \\
\hline & Strategic plan & 5 & 18 & \\
\hline \multirow{4}{*}{$\begin{array}{c}\mathrm{E} \\
\text { Innovative }\end{array}$} & Develop current product & 4 & & \multirow[t]{4}{*}{ Likert scale } \\
\hline & Develop current production & 3 & & \\
\hline & Source of supply & 3 & & \\
\hline & Structure in management & 3 & 13 & \\
\hline \multirow{4}{*}{$\begin{array}{c}\mathrm{F} \\
\text { Grab Market Opportunities }\end{array}$} & To study market & 4 & 12 & \multirow[t]{4}{*}{ Likert scale } \\
\hline & To study market & 4 & & \\
\hline & Strong character & 3 & & \\
\hline & $\begin{array}{l}\text { Grab opportunities based on } \\
\text { strength }\end{array}$ & 5 & & \\
\hline
\end{tabular}

Table 2. Population, Sample and Respondents' Replied in Kraftangan Malaysia

\begin{tabular}{llrrrrrr}
\hline \multicolumn{1}{c}{ Zone } & \multicolumn{1}{c}{ State } & Populations & \multicolumn{2}{c}{ Sample } & \multicolumn{2}{c}{ Return Back } \\
& & $\boldsymbol{P}$ & $\boldsymbol{s}$ & & \\
\hline West-Coast Malaysia & Kuala Lumpur & 17 & 136 & 3 & 30 & 1 & 22 \\
& Selangor & 34 & & 8 & & 6 & \\
& Melaka & 17 & & 4 & & 3 & \\
& Negeri & 68 & & 15 & & 12 & \\
& Sembilan & & & & & & \\
& Terengganu & 190 & 297 & 41 & 64 & 39 & 62 \\
& Pahang & 78 & & 17 & & 17 & \\
& Kelantan & 29 & & 6 & & 6 & \\
\hline East-Coast Malaysia & Sabah & 354 & 439 & 75 & 93 & 75 & 93 \\
& Sarawak & 85 & & 18 & & 18 & \\
\hline East Malaysia & Perlis & 19 & 447 & 4 & 94 & 4 & 94 \\
& Pulau Pinang & 55 & & 12 & & 12 & \\
& Kedah & 129 & & 26 & & 26 & \\
& Perak & 244 & & 52 & & 52 & \\
& Johor & 28 & 28 & 28 & 28 & 24 & 24 \\
\hline South-Peninsular Malaysia & & 1347 & 1347 & 309 & 309 & 295 & 295 \\
\hline & Total & & & & & &
\end{tabular}


Table 3. Test Statistic on Demographic Profile

\begin{tabular}{|c|c|c|c|}
\hline Hypothesis & Tests & $\operatorname{Res}$ & \\
\hline $\begin{array}{l}\text { H1 (Difference on gender } \text { toward } \\
\text { entrepreneurial personality) }\end{array}$ & $\begin{array}{l}\text { Mann-Whitney U } \\
\text { Test }\end{array}$ & $\begin{array}{l}U=10108 \\
P=0.310\end{array}$ & Rejected \\
\hline $\begin{array}{l}\text { H2 (Difference on age toward entrepreneurial } \\
\text { personality) }\end{array}$ & $\begin{array}{l}\text { Kruskall-Wallis } \\
\text { Test }\end{array}$ & $\begin{array}{l}X 2=2.663 \\
P=0.616\end{array}$ & Rejected \\
\hline $\begin{array}{l}\text { H3 (Difference on education level toward } \\
\text { entrepreneurial personality) }\end{array}$ & $\begin{array}{l}\text { Kruskall-Wallis } \\
\text { Test }\end{array}$ & $\begin{array}{l}X 2=6.306 \\
P=0.098\end{array}$ & Rejected \\
\hline $\begin{array}{l}\text { H4 (Difference on field of study toward } \\
\text { entrepreneurial personality) }\end{array}$ & $\begin{array}{l}\text { Kruskall-Wallis } \\
\text { Test }\end{array}$ & $\begin{array}{l}\mathrm{X} 2=1.121 \\
\mathrm{P}=0.772\end{array}$ & Rejected \\
\hline
\end{tabular}

Table 4. Test Statistic on Business Profile

\begin{tabular}{|c|c|c|c|}
\hline Hypothesis & Tests & Resul & \\
\hline $\begin{array}{l}\text { H5 (Difference on zones of operation toward } \\
\text { entrepreneurial personality) }\end{array}$ & $\begin{array}{l}\text { Kruskall-Wallis } \\
\text { Test }\end{array}$ & $\begin{array}{l}\mathrm{X} 2=26.113 \\
\mathrm{P}=0.000\end{array}$ & Accepted \\
\hline $\begin{array}{l}\text { H6 (Difference on paid-up capital toward } \\
\text { entrepreneurial personality) }\end{array}$ & $\begin{array}{l}\text { Kruskall-Wallis } \\
\text { Test }\end{array}$ & $\begin{array}{l}X 2=0.686 \\
P=0.710\end{array}$ & Rejected \\
\hline $\begin{array}{l}\text { H7 (Difference on sales turnover toward } \\
\text { entrepreneurial personality) }\end{array}$ & $\begin{array}{l}\text { Mann-Whitney U } \\
\text { Test }\end{array}$ & $\begin{array}{l}\mathrm{U}=1480.0 \\
\mathrm{P}=0.255\end{array}$ & Rejected \\
\hline $\begin{array}{l}\text { H8 (Difference on number of employees } \\
\text { toward entrepreneurial personality) }\end{array}$ & $\begin{array}{l}\text { Kruskall-Wallis } \\
\text { Test }\end{array}$ & $\begin{array}{l}\mathrm{X} 2=2394.5 \\
\mathrm{P}=0.004\end{array}$ & Accepted \\
\hline
\end{tabular}

